\title{
The Development Path of transformation and upgrading of Chinese Manufacturing Industry under the background of "the Belt and Road"
}

\author{
Cai xiaoyan \\ Shanghai University of Engineering Science \\ Shang Hai, China \\ purple1991cxy@126.com
}

\begin{abstract}
Since the outbreak of the U.S. financial crisis, the annual output value of China's manufacturing plummeted, and exports blocked. What's more, with the continuous reduction of the demographic dividend and the rising cost of manufacturing, making the transformation and upgrading of the manufacturing industry had to speed up the process. The whole situation of China with its neighboring countries is in the best period of history, and the resources of the surrounding countries are different, with strong economic complementarity and great potential for cooperation. So through this strategy of the Belt and Road can promote the efficient allocation of resources and market depth integration, to accelerate the transformation and upgrading of China's manufacturing industry, to enhance the international competitiveness.
\end{abstract}

Keywords-the Belt and Road; transformation and upgrading; manufacturing industry

\section{INTRODUCTION}

The Silk Road began in ancient China, and the initial role is to transport silk, porcelain and other goods. As time goes on, Silk Road become collectively all political, economic and cultural exchanges channel in ancient China and the West. The world today is undergoing complex and profound changes: world multi-polarization and economic globalization, cultural diversity, etc. The international financial crisis revealed deepseated influence, the slow recovery of the world economy and the development of differentiation, international investment and trade patterns and multilateral trade and investment rules profound adjustment. Countries facing the development of the problem is still grim. Chinese economy and the world economy are highly associated, building the Belt and Road to the trend of the times, upholding the spirit of open regional cooperation, efforts to safeguard the global free trade system and open world economy.

Since the outbreak of U.S. financial crisis in 2008, China's manufacturing industry being affected by it, the annual output value is slumped, and export is blocked. Especially after 2012, superimposed with the RMB appreciation, export tax rebate reduction, more expensive labor, prices of raw materials and many other factors, make the manufacturing costs increased by about $30 \%$. Although the country has introduced policies to help the manufacturing industry gradually out of the trough and benefit also show a continued rebound phenomenon. But in recent years, due to various factors, the demographic dividend continues to decrease, so that manufacturing industries have to speed up the process.

Faced with such a complex situation, scholars from different research perspectives have been studied and developed different theories and suggestions. Zhao Chunming (2016) thought we should implement green manufacturing development [1]. Yin xiang and Yang Jirui(2016) thought we should be based on our comparative advantage and the internationalization of the stage, selecting the overseas market which is consistent with the development of the enterprise, to achieve the depth of participation in the global trade division of labor and the optimization and upgrading of the production organization structure is of great significance [2]. Based on the framework of "global factory"theory, Wang Junjie and Yu Pei (2015) analyzed the sustainable development of manufacturing industry in China [3].

Essentially, manufacturing transformation and upgrading of the situation is irreversible. We can't reverse this trend fundamentally, but only under the premise of its adaptation, grasping the opportunity and development of the transformation and upgrading of manufacturing industry. This paper is under the background of The Belt and Road, exploring the transformation and upgrading of China's manufacturing problems, which are not intended to solve this problem, but gives a reasonable proposal that how we think and how we act.

\section{THE EFFECT OF THE BELT AND ROAD ON MANUFACTURING} INDUSTRY

The President Xi put forward the concept of the Belt and Road when he visited Central Asia and Indonesia. Countries along the Belt and Road have different resource endowments, strong economic complementarity and great mutual cooperation potential. Taking policy communication, facilities connect, trade flow, financing, common aspiration of the people as the main content, while infrastructure interconnection is the priority areas of the Belt and Road to construct. China is the country which has the most ability to carry on the infrastructure construction in the present world, and China in this area has accumulated a wealth of technical experience. 
The Belt and Road is proposed to deepen our country along with the national and regional comprehensive economic and trade relations. In this process, The great development potential of interior countries and regions along the Belt and Road is expected to be transformed into a huge driving force of China's manufacturing overseas development. In the background of China having become the capital exporting country, the Belt and Road will become China's key ring to accelerate economic spatial structure optimization and enhance the international competitiveness.

The sixty-five countries along the Belt and Road, include the industrialization process at all stages. Eight countries with China at the same stage of industrialization respectively are Malaysia in the Southeast Asia, Poland, Slovakia and Romania in the Central and Eastern Europe, Turkey, Bahrain, Lebanon and Jordan in the West Middle East, nine levels of industrialized countries are higher than China, and forty-seven levels of industrialized countries in the junior middle period of industrialization stage are lower than China. With the enhancement of the national industrialization level, whether it is infrastructure investment or consumer demand, will provide a huge space for the development of Chinese industry. In 2013 China and the other sixty-four countries' import and export trade volume accounted for only $11.5 \%$ of the total trade volume of all sixty-four countries, accounting for $25 \%$ of China's total trade, which means that the international cooperation capacity of China and the countries of the Belt and Road has just started, a huge room for growth. Therefore, the implementation of the Belt and Road on the development of Chinese traditional industries, especially has an important meaning to optimize the structure of production [4].

Promote Chinese manufacturing industry from large to strong. Over the past ten years, China's manufacturing industry has developed rapidly, manufacturing value added in twentyfirst Century to catch up with Germany, Japan and the United states, whether manufacturing output, import and export or the number of employees, both at the global leader, become a veritable manufacturing power.

\section{ANALYSIS OF THE CURRENT SitUATION OF CHINA's MANUFACTURING INDUSTRY}

\section{A. Development Status}

Since the reform and opening up, China's manufacturing industry has developed rapidly, and it has swept the world in more than ten years. Now, in any corner of the world, you can feel the power of Chinese manufacturing, and there is no doubt about the status of the world's factory. Manufacturing industry is the engine of China's economic growth and development, but also the foundation of China's economic transformation. According to statistics, between 2007 and 2013, China's industrial output value accounted for $40 \%$ of GDP on average. Effects of various industries on GDP are shown in Fig.1: Secondary industry in the national economy (GDP) has played an important role and occupied in the dominant position, correspondingly, the proportion of primary industry declined. At this stage, the proportion of tertiary industry increased. The rapid development of the service industry let us more clearly aware that the future of product services is the trend of the times. Analysis of the current situation of China's three industrial structures, and international comparison, we can make an objective understanding of China's backward. China's industrialization is far from complete, and there is still a long way to go.

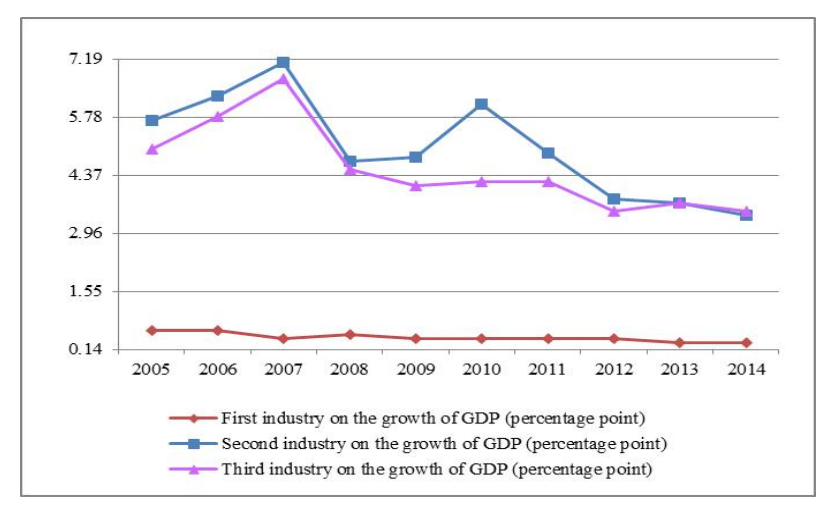

Fig. 1. Three industries to the growth of GDP

Data sources: National Bureau of Statistics of China. http://data.stats.gov.cn/ks.htm?cn=C01

The manufacturing industry has obvious effect on the GDP, but it shows a downward trend. When purchasing managers' index (PMI) is higher than 50\%, it reflects the expansion of the manufacturing economy, otherwise it reflects the economic contraction. Fig. 2 shows, from nearly a year of manufacturing PMI index, since August 2015 to February 2016, it has seven consecutive months below the ups and downs of the line, showing manufacturing growth pressure. Until February 2016 reached the lowest value and then gradually expand, showing a rising trend. Although the PMI index rebounded slightly, the overall economy is still sluggish. After the rebound it changed slightly and a slight decrease, then it had to face challenges to upgrade again.

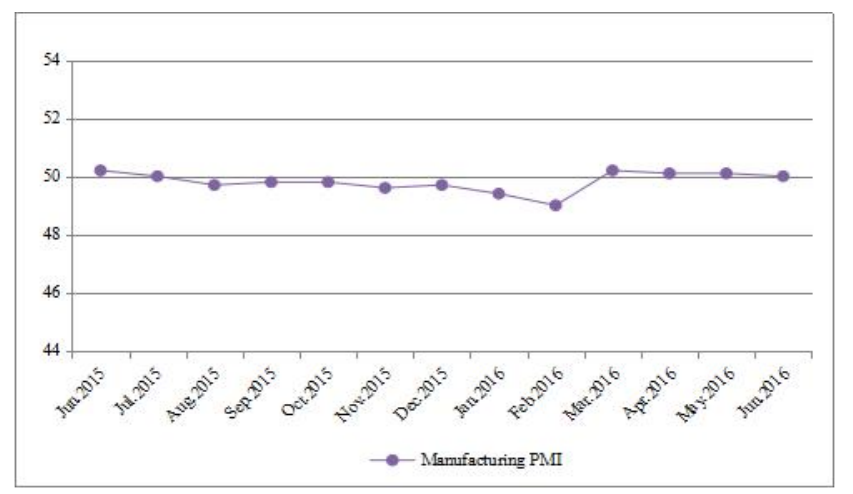

Fig. 2. Manufacturing PMI

Data sources: National Bureau of Statistics of China.http://data.stats.gov.cn/swf.htm?m=turnto\&id=433

\section{B. Problems}

The development model of China's manufacturing in the past mainly depends on the factor driven, especially the demographic dividend and investment driven. But in recent years, we can see that China is facing the dual pressures of manufacture: internal labor costs and operating costs continue to rise, the external economic situation continues to decline, and the trade date is from bad to worse. Low-end 
manufacturing is facing the development of low cost competition in Southeast Asia and developing economies, while high-end manufacturing needs to resist the impact of the developed countries. Under both internal and external pressures, it begins to enter a new normal.

\section{- Excess production capacity}

Deeply affected by the international financial crisis, the international market continues to slump and domestic demand growth slowed down. China's oversupply of some industries has become increasingly prominent, and the traditional manufacturing overcapacity, especially in steel, cement, electrolytic aluminum and other high consumption, high emission industries are particularly prominent [5]. Due to the low capacity utilization, our long-term backlog of production capacity can't be fully utilized and effective released, thus it becomes a major mishap for our manufacturing industry.

\section{- Cost advantage gradually weakened}

In recent years, as China's demographic dividend disappearing, foreign manufacturing industry is gradually transferred to countries with lower labor costs in Southeast Asia as well as India, Brazil and Mexico. As the United States put forward the concept of manufacturing, the future of China's manufacturing industry should be able to consider how to enhance the long-term as well as the ability to create Chinese industrial investment and business environment, rather than merely in the early stages of the foundry. For China, the development of international investment is an important way to participate in the global value chain reconstruction, to achieve industrial upgrading and technological progress.

\section{- Lack of independent innovation}

Our equipment manufacturing industry is big but not strong, mainly lacking of original design ideas and philosophy from the inside enterprise, and the weak of the equipment manufacturing capacity for high-tech industries. In the final analysis, our country's innovative ability is insufficient in the equipment manufacturing industry, core technology controlled by others, and made in China is still in the low end of the value chain. With the acceleration of China's industrialization and the process of economic globalization, manufacturing industry has become an indispensable part of the national economy. Manufacturing technology level directly affects the growth rate and quality of the entire economy [6].

\section{Policy ReCOMMENDATIONS}

The countries along the Belt and Road are emerging and developing countries, in the urbanization or industrialization starting or accelerating stage, often facing the difficulties of the shortage of funds, backward technology experience. In the premise of the pursuit of mutual benefit and win-win, using production cooperation under the strategy of the Belt and Road, also need to comply with the economic development along the country in seeking overseas development space for China's manufacturing industry at the same time.
First of all, resolve the excess capacity of China's manufacturing industry. Excess capacity is one of the major bottlenecks in the development of China's manufacturing industry. The countries' the huge market capacity along the Belt and Road is expected to become the overseas undertaking of China's low-end labor-intensive industries and overcapacity industries. The acceleration of industrial transfer will promote the upgrading of manufacturing structure through the transfer effect of traditional industry value chain and the reorganization of production factors, and create conditions for China's manufacturing industry to foster new advantages of international competition [7].

Secondly, expand production capacity to work together to promote common development. With the rise of China's labor costs and the reduction of the population bonus, some of the comparative advantage in manufacturing industry is declining, and it can gradually transfer some industries to the developing countries in the lower stage of development. Based on the 30 years of development experience of China's manufacturing industry, the development level of manufacturing industry is improved according to the characteristics of the region. To take advantage of the strategy of the Belt and Road to complete the eastern part of the backward production capacity of industrial transfer and manufacturing development in the western and northeastern regions.

Last but not the least, learn from the experience of the international developed countries, and enhance the ability of independent innovation. China's manufacturing industry to move towards the high industrial value chain must be through technological innovation, break through the key core technology, and gradually guide the manufacturing industry's transformation from production to serviceoriented manufacturing. And the United States and other developed countries have a rich experience, so we can combine our own characteristics to enhance the ability of self-innovation.

\section{CONCLUSION}

At present, China's manufacturing industry is facing unprecedented challenges, squeezed twice by the high-end manufacturing to reflux and low transfer of manufacturing to low-cost countries. Therefore, the construction of the Belt and Road promotes the orderly and free flow of economic factors, efficient allocation of resources and market depth of integration, to promote the coordination of economic policy in countries along the line, to carry out a larger, higher, deeper level of regional cooperation, to create an open, inclusive, balanced, inclusive Regional Economic Cooperation Framework together, to structure industry ecosystem and new manufacturing mode under conditions of information. It has a very important practical significance, as a recipe to promote the transformation and upgrading of China's manufacturing industry.

\section{ACKNOWLEDGMENT}

First of all, I would like to extend my sincere gratitude to the conference organizers, for giving me a chance to exercise myself. High tribute shall be paid to my teacher Mr. Zhang for his instructive advice and useful suggestions on my thesis. 
Special thanks should go to all my friends and other teachers in Translation Studies for their direct and indirect help to me.

Finally, thanks to the authors of the papers cited, it is because of their research, I can better move forward.

\section{REFERENCES}

[1] C.M. Zhao, and H. Xue, "The develop strategy of "The Belt and Road" and green industry in China," 2016, pp. 137-142.

[2] X. Yin and J.R. Yang, "Analysis on the path and countermeasure of the internationalization of China's high-end equipment manufacturing industry," Economists, 2016, pp. 103-104.
[3] P. Yu and J.J. Wang, "Research on the path of sustainable development of Chinese manufacturing industry under the new normal based on "global factory" perspective," Contemporary finance \& Economics, 2015, pp. 98-107.

[4] Q.H. Huang and X.H. Li, "China's industrial development during the "12th Five-Year" assessment and "13th Five-Year" strategy," China Industrial Economy, 2015, pp. 5-20.

[5] "The guidance of the State Council on resolving serious excess capacity of production," The State Council Information Office of the People's Republic of China, State Council, 2013.

[6] Y.B. Xiang and C.F. Zheng, "Countermeasures of improving the international competitiveness of China's equipment manufacturing industry," Economic aspect, 2013, pp. 74-76.

[7] H. Su, "Study on the overseas transfer of China's manufacturing industry under the strategy of the Belt and Road," International trade, 2015, pp. 18-21. 